\title{
Self-Healing Superhydrophobic Fluoropolymer Brushes as Highly Protein-Repellent Coatings
}

\author{
Zhanhua Wang, ${ }^{1,2}$ and Han Zuilhof ${ }^{2,3, *}$
}

E-mail: Han.Zuilhof@wur.nl ; phone: +31 317482361

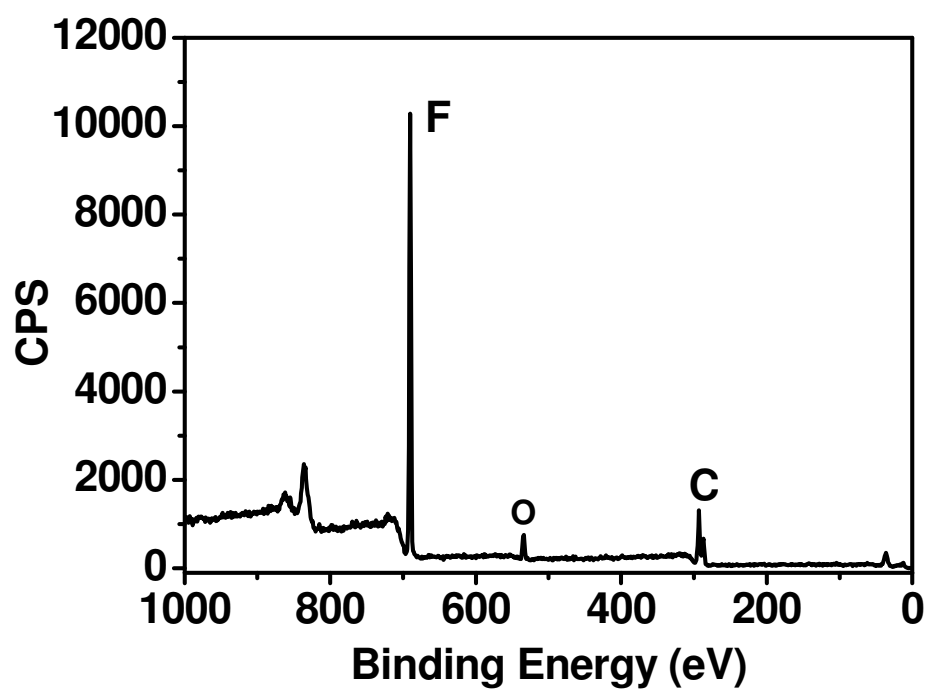

Figure S1. XPS wide scan of PMAF17 brush-modified nanostructured Si surface. 